\title{
AN AUTOPSY OF COOPERATION: DIAMOND DEALERS AND THE LIMITS OF TRUST-BASED EXCHANGE
}

\author{
Barak D. Richman*
}

\section{ABSTRACT}

Both academic and popular representations of the diamond industry describe trustbased relations and an industry arbitration system that sustain trade. In recent years, however, trust among merchants has eroded, and merchants have correspondingly lost confidence in the industry's arbitration. This article describes the events that have led to the breakdown of cooperative trust in the industry and derives lessons regarding the nature and limits of reputation-based exchange in the modern economy.

[W] hen I first entered the business, the conception was that truth and trust were simply the way to do business, and nobody decent would consider doing it differently. Although many transactions are still consummated on the basis of trust and truthfulness, this is done because these qualities are viewed as good for business, a way to make a profit. -Elderly diamond dealer, quoted in Bernstein (1992).

It used to be like that. It's not like that anymore.

-Long-time diamond dealer, to author on 47th St. (2015).

\section{INTRODUCTION}

A New York Times reporter, writing about the city's diamond district in 1984, marveled at how diamantaires "trust each other not to walk away with the world's most valuable, easily concealed commodity" and concluded that

* Edgar P. and Elizabeth C. Bartlett Professor of Law and Business Administration, Duke University, PO Box 90360, Durham, NC 27708-0360, USA. Tel.: +1-(919)-613-7244; E-mail: richman@law.duke.edu. The author is indebted to Sara Sternberg Greene, Kathryn Spier, Lisa Bernstein, Alan Morrison, two anonymous reviewers, and the editors of the Journal of Legal Analysis for feedback that vastly improved this article.

The Author 2017. Published by Oxford University Press on behalf of The John M. Olin Center for Law, Economics and Business at Harvard Law School.

This is an Open Access article distributed under the terms of the Creative Commons Attribution Non-Commercial License (http://creativecommons.org/licenses/by-nc/4.0/), which permits non-commercial re-use, distribution, and reproduction in any medium, provided the original work is properly cited. For commercial re-use, please contact journals.permissions@oup.com 
mutual trust was the "real treasure of 47th Street" (Starr 1984). Writing eight years later, in perhaps the most important article written about the diamond trade, Lisa Bernstein (1992) similarly observed that obtaining access to a supply of rough diamonds requires "maintain[ing] a reputation for scrupulous honesty" (Bernstein 1992, p. 119). And popular authors, attracted to the romance of the diamond trade, have extolled the virtues of trust among merchants, intimate family businesses, and communities built around the moral fiber of business ethics. Russell Shor (1993), a prominent diamond industry journalist, wrote "legal and moral accountability is the foundation for the very survival of the diamond trade" ("Even if 1 percent of the dealers were dishonest," a dealer tells Shor, "that trust would be destroyed and so would our industry") (p. 12). Renee Rose Shield (2002) relates in a beautiful ethnography of 47th Street that "formal contracts are unnecessary since informal contracts are heavy with moral weight and embody certain principles: to honor commitments, to produce a good product and to stand behind it, and to preserve reputation" (p. 102). And journalist and child of diamond dealers Alicia Otulski echoes what the New York Times observed almost thirty years earlier: "At any given moment on 47th Street a dealer may be in possession of hundreds of thousands of dollars' worth of another man's diamonds. Usually, he has not paid the owner any collateral, only his word ... In this business, everything works on credit, loan, and trust" (Oltuski 2011, p. 7). ${ }^{1}$

This has been the diamond industry's narrative. Mutual trust binds diamantaires to their pledges and to each other, and such trust-based exchange serves as a substitute for state-sponsored courts and conventional law. These stories illustrated how an insular merchant community could construct social networks that sustain mutually beneficial trade, despite the enormous risk posed by cheating (Richman 2004; 2006). They served not only as the backbone for academic understandings of the industry, but as proof of how arbitration, reputations, and social networks could fully supplant the state-sponsored legal system (see e.g. Bernstein 1992).

But gradually, the stories changed. Consider one typical telling from a diamond dealer in Antwerp, in 2013:

There are not many frauds, not many thieves. People trust and try to make deals work for both sides. But there are some people who cheat. ... And they reenter the business, by putting the company in a relative's name, by paying with cash and getting new contacts and new

1 One of the diamond industry's great paradoxes is the admiration with which commentators speak of diamond dealers and the middlemen within the distribution chain, versus the vitriol with which other commentators speak of De Beers and mining interests that sit atop the distribution chain. For critical assessments of De Beers, see, e.g. Kanfer (1993) and Roberts (2003). 
trust. That's what happened to me, I was cheated and I see the cheater back on the streets here. There's nothing I can do about it (Richman 2013).

He tells this story only after repeating the familiar platitudes of trust among diamantaires, how earning and maintaining trust is necessary to succeed. But when he shares this recent and clearly painful experience, he opens up; he expresses regret for what the industry has become, and he concedes he is urging his son and nephew to pursue alternative careers. The return of an undisputed cheater is difficult to reconcile with the traditions and norms of the industry in which he was raised and to which he has devoted many decades. Many other dealers share his deep disappointment in what has become of the diamond industry and agree that the deterioration of the proverbial bonds of trust mark a meaningful change in the world of diamond merchants.

First-hand accounts from the industry over the past twenty years have followed this same arc: widespread trust was reported in 2000 , then a growing number of incidents of dishonest conduct in the years that followed, and now mostly laments that the industry is no longer what it was. Accounts by dealers and revelations in industry publications indicate that persistent and calculative cheating is becoming almost commonplace. Dealers fail to pay for items purchased on credit and yet continue participating in the industry. "Upgrading," which occurs when a diamantaire purchases gems with certain Gemological Institute of America (GIA) grades (on clarity, color, carat, and cut) and then convinces gem evaluators to give those same gems higher grades, is becoming increasingly common (Rapaport 2005; Times of India 2015). A variety of laser treatments are used to enhance diamond color or hide occlusions without necessary disclosures to subsequent buyers (for a variety of clever techniques, see Diamond Helpers 2015). And there are frequent instances of synthetic diamonds, which have market values approximately 30 percent lower than corresponding natural diamonds, being mixed with and presented as natural diamonds (Rapaport 2013; Sherman 2014). The growing deceitfulness prompted one longtime industry observer put it succinctly: "It doesn't pay to be honest anymore. When you're honest, you're viewed as a sucker" (Richman 2015). ${ }^{2}$

2 A new brazenness also appears to have also infiltrated cheating on 47 th Street. In a recently uncovered years-long scheme, a group of twelve diamond dealers convinced many fellow dealers to part with valuable gems on empty promises or fraudulent maneuvers. The defrauders also wrote bad checks, forged documents, and wrapped wads of $\$ 1$ bills in single $\$ 100$ bills to mask underpayments. When one defrauded dealer confronted one of the thieves, the thief reportedly said, "Take me to court ... I pay you when I feel like it ... Nobody can do [anything] to me. If I need, I [cheat] somebody if I want." (Whitehouse 2017). 
Trust is even breaking down within what legal scholars might call the diamond industry's crown jewel: its private arbitration system. When Lisa Bernstein brought the New York Diamond Dealers Club's (DDC) arbitration system to scholars' attention in 1992, she reported that the industry's system of private dispute resolution "enables parties to resolve disputes and enforce judgments quickly, inexpensively, and secretly" (p. 148). She further heralded the arbitration system for exhibiting expertise, accuracy, discretion, and fidelity, and other industry admirers lavished the DDC's private legal system with similar praise. Renée Shield described the "courtly system of arbitration" as "the crowning achievement of the diamond business and is emblematic of how trust and reputation are the stellar symbols of the trade" (2002, p. 7).

Recent portrayals of the industry's dispute resolution system have not been as flattering. An industry watchdog remarked, "we have witnessed a serious erosion of [mutual] trust" in the industry's arbitration system, and increasingly, there are "bourse members who believe that an Israeli arbitration panel will always decide against a New York party and that a New York arbitration panel will always go against an Israeli party in the dispute" (Even-Zohar 2008b, p. 12 ). Whereas the arbitration system previously provided a cornerstone for transactional security, with the 1984 New York Times reporter remarking that "The club is responsible for arbitrating disputes. To flout its decision is to risk loss of membership, a disgrace and an economic blow," (Starr 1984), the watchdog now observes:

The quite sudden vanishing of the trust-based system, its breakdown or even collapse, has left a vacuum. The industry is at a loss to comprehend and find guidance regarding how to operate in a vacuum without a newly agreed common set of norms. The time-honored rules, including those governing the diamond bourses, seem to have become increasingly irrelevant. It has been argued that the fabric holding a bourse together is the internal arbitration system. In Israel, this summer, we saw a highly respected company opt to have its disputes adjudicated in a court after an unfavorable (to it) arbitration experience. This illustrates the vacuum in norms and standards with which diamond merchants need to cope (Even-Zohar 2017, p. 8).

A contributing cause for eroding respect for arbitration rulings has been dogging accuations of impropriety by arbitrators. There has been a growing incidence of judgments rendered in absentia, in which one party, usually a nonmember, claims not to have received fair notice before a default judgment is rendered against him (Even-Zohar 2008b). For example, one nonmember suing the DDC in 2007 claimed in an affidavit, "It was obvious that the [DDC] was not attempting to reasonably consider the issues of jurisdiction or 
whether I was even involved with the claim, but instead wanted to protect its members... ." (Sanghvi v. Diamond Dealers Club, Inc.). In a similar incident in 2006, a diamond dealer from Texas sued a DDC member in New York court for failing to return a flawless 25.4 carat diamond; the DDC member argued that the DDC arbitration board had exclusive jurisdiction over the dispute, and testifying on his behalf was the chairman of the DDC, who had a separate disagreement with the Texas dealer. Recognizing that the DDC members were manipulating DDC arbitration procedures to team up against the outsider, the court retained jurisdiction over the dispute and the magnificent gem was returned (Stettner $v$. Twersky).

DDC arbitrators have also been accused of being complicit in schemes by fellow DDC members to swindle consumers with inflated and fraudulent GIA certificates (Even-Zohar 2008a). For some, the problems concerning DDC arbitration are reaching a crisis point, compelling one observer to confide in an email that "the quality of [DDC] arbitration (i.e. the kind of justice that is being rendered) has so deteriorated, that people are resigning their DDC membership, to avoid the chance that in a business dispute they may be forced to agree to arbitration" (Richman 2009b). As a result, a leading industry expert has lamented that "the DDC, once upon a time one of the most important and prestigious bourses in the world, sees its membership declining" (Even-Zohar 2008a, p. 4676).

DDC leadership, rather than being a bulwark against declining trust, appears to be contributing to the credibility decline. A report commissioned in 2011 revealed that the Club, from 2006-2009, suffered from severe financial mismanagement, a failure of leadership, and accounting irregularities. An accompanying exposé reported "unapproved or unjustifiable expenses incurred by the club's president, the granting of questionable loans, and activities hidden from the board of directors" (Even-Zohar 2011, p. 1). These reports followed a particularly ugly internal legal battle in which a vice president of the DDC sued the Club and its president for engineering questionable procedural maneuvers, including permitting select nonmembers to participate in a vote that awarded the then-president additional terms. (In an affidavit, the vice president asserted that since president's election, "there has been a consistent and increasing erosion in how the By-laws, rules, and 78-year-old traditions and customs of the Club have been observed and executed," and specifically that the president "peddled" reductions in unpaid dues "in order to gain their votes in the election." Abraham v. Diamond Dealers Club.) Allegedly, the president's central motivation for maintaining his office was to bestow favors to certain colleagues, including exempting membership fees and rigging arbitration decisions. It seems that trust is not only eroding among diamantaires but the institutions designed to sustain industry-wide trust are losing credibility. 
This article examines the developments that have brought such stark changes to 47 th Street and have led longtime industry observer Chaim Even-Zohar to remark that "the diamond industry is in the middle of a constructive upheaval" (2007, p. 1). Specifically, it investigates the causes of why trust is breaking down-or, in accordance with an economist's explanation, why so many diamond dealers now find short-term strategies more attractive than long-term strategies associated with investing in and preserving a good reputation. It first outlines how trust-based cooperation among diamantaires had sustained cooperation and enforced executory agreements without relying on state coercion. It then reviews the many structural changes that have taken place in the past twenty years to each of the industry's three major market levels-diamond production, retail sales, and middleman markets - and it investigates how these changes might explain why the benefits of cooperation no longer overcome the temptations for short-term gains. Since the diamond industry has been held as the paradigmatic industry in which reputations and private ordering govern exchange, the demise of cooperation in the industry has implications for foundational scholarship that had presupposed the industry's ongoing cooperation. The article revisits some of these seminal discussions and aims to derive broader lessons from the diamond experience for the sustainability of self-enforcing governance and trust-based exchange.

\section{THE COOPERATIVE EQUILIBRIUM}

In order to understand the breakdown of cooperation in the diamond industry, one must first understand how the industry has managed to sustain cooperation. And to understand how cooperation was sustained, one must first understand why cooperation is necessary.

The most significant feature of diamond transactions is the unreliability of state courts in enforcing executory contracts. The typical diamond transaction is a credit sale or a brokerage arrangement-situations in which a diamond or cache of diamonds is in the possession of someone who is not the owner. Because diamonds are easily portable, virtually untraceable, and command high prices throughout the world, a potential thief encounters few obstacles in hiding unpaid-for or stolen diamonds from law enforcement officials, fleeing American jurisdiction, and selling the valuable diamonds to black market buyers. Accordingly, state courts can neither discipline parties nor seize stolen assets that escape their jurisdictional reach. Even sophisticated legal instruments, such as liens or other devices to secure collateral, cannot reliably prevent diamond theft, which in the language of contract law is the failure to pay for a sale on credit. These important limitations on the capabilities of state 
courts force the diamond industry to depend instead on private mechanisms to enforce contracts: in short, parties have relied on trust because courts cannot provide relief.

Instead, the industry relies on an elaborate reputation mechanism that rests on sustained cooperation. The mechanics of this reputation mechanism, which disseminates accurate reputational information and mobilizes collective punishments, is described in detail elsewhere (see Bernstein 1992; Richman 2004, 2006). But the underlying economics are like conventional reputation mechanisms, in which cooperation is sustained so long as the benefits of future cooperation outweigh the benefit of one-time cheating.

\subsection{The Theory of Self-Sustaining Reputation Mechanisms}

Reputation mechanisms typically arise to overcome the prisoners' dilemma of enforcing promises. For each profit opportunity, individuals make promises (such as on the quality of an offered good or service or to make a payment in the future) to business partners that those partners cannot verify until after a transaction takes place. If the long-term profits from keeping promises exceed the shorter-term profits from breaching or cheating, then promises will be kept in equilibrium. Modeling complexities arise when cooperation involves many merchants who do not know each other intimately, and when successful cooperation invites competitive entry. The model employed here relies on Milgrom, North, \& Weingast (1990) to solve the multilateral challenge and on Klein \& Leffler (1981), modified by Rasmusen (1989), to resolve the dynamics of entry.

Milgrom, North, \& Weingast (1990) formally modeled how individuals in a community of merchants will be motivated to keep promises made to each other even when any particular merchant pair transact infrequently. The model begins with a classic Prisoners' Dilemma game in which the collective gains from cooperative trade is $\pi$, shared equally between the two merchants. If one party cheats the other, the cheater gains $\alpha$ and the cheated results with $-\beta$ (and both get zero if neither aims to cooperate). In accordance with the Prisoners' Dilemma construct, cooperation is socially efficient $(\pi>\alpha-\beta ; \pi>0)$ and the benefits from cheating is greater than a one-time reward from cooperating $(\alpha>\pi / 2)$. The model additionally introduces Law Merchants (LM) who both arbitrate disputes between merchants and serve as custodians of reputation information. For a cost of $Q>0$, merchants "can query the LM for the records of previous judgments about any other player. Without querying the LM, players have no information about their current partners' trading history." (p. 10, emphasis in original).

The power of the Milgrom, North, \& Weingast (1990) model is that a system that disseminates reputational information and triggers reputational sanctions 
can be sufficient to secure impersonal trade. When merchants pay $Q$, which simply represents a tax to sustain an information infrastructure, they learn of their trading partner's reputation even if the two had never met. Mathematically, the model demonstrates that if all merchants have a sufficiently high discount rate, $\delta$, cooperation can be sustained among a large number of traders if each member adopts an Adjusted Tit-for-Tat (ATFT) strategy (i.e. a merchant will cooperate with every merchant that has cooperated in the past and will defect against any merchant who cheated another merchant in the past). In cooperating, each merchant earns $(\pi / 2-Q)$ each period, and the profits from multilateral longterm cooperation will be sufficient to overcome the temptation of cheating one time if:

$$
[(\pi / 2)-Q] /(1-\delta) \geq \alpha
$$

This inequality also describes the reputational forces at work in the diamond industry. Remarkably, the diamond industry has historically been able to sustain cooperation among merchants despite the enormous potential profits from cheating (simply, stealing another's diamonds). In the language of the Prisoners' Dilemma, such lucrative cheating is denoted by $(\alpha \gg \pi / 2>0)$. Ongoing cooperation therefore relies on a high valuation of future wealth, a high certainty that profitable transactions will continue deep into the future (both of which are represented by a high discount rate, $\delta$ ), and rigorous institutional supports that provide highly credible reputation information. ${ }^{3}$

However, the Milgrom, North, \& Weingast (1990) model was designed to depict how reputation mechanisms could induce longterm cooperation among merchants from across regions and trading multiple products. The model views each merchant pair and each trade as an independent source of economic surplus, and thus it does not account for how profitable trade might invite entry by new merchants or how such profits or entry would affect prices. Applying the Milgrom model to understand profitable cooperation in a single market requires converting $\pi$ from an exogenous parameter into an endogenous variable that is sensitive to entry and price competition.

Klein \& Leffler (1981) modeled a reputation mechanism in which sellers could produce goods of either low or high quality. Sellers of a good for price $p$ have an option of manufacturing either a high or low quality product,

3 To sustain cooperation, merchants must have accurate and timely information about their trading partners' past dealings, and the merchant community must impose credible and sufficiently painful punishments to deter misconduct (or reciprocally, the merchant community must credibly assure sufficiently high benefits for longterm honest conduct). The institutions that both disseminate information and coordinate punishments in the diamond industry are discussed in detail in Richman $(2004,2006)$. 
respectively costing $c_{\mathrm{h}}$ and $c_{1}\left(c_{\mathrm{h}}>c_{1}\right)$, yet purchasers cannot observe quality until after purchase. If purchasers will only purchase goods from sellers who have only produced high quality goods in the past, sellers will produce high quality goods only if the expected profits of $\left(p-c_{h}\right)$ for infinite periods outweigh the one-time profit of $(p-q)$. However, if per-period profits selling highquality goods are positive $\left(p-c_{\mathrm{h}}>0\right)$, then new entrants will produce the same goods, thus reducing the market price $p$ and undermining the high-quality equilibrium. Rasmusen (1989) depicts this constraint on endogenous $p$ by simplifying Klein \& Leffler (1981) and incorporating a fixed sunk-cost $F$, where

$$
\left(p-c_{\mathrm{h}}\right) /(1-\delta)=F .
$$

Thus, the sunk costs required to enter the market are equal to expected longterm profits, and new competitors are indifferent to entry.

Historically, entry barriers have been central and pervasive in the diamond industry, and thus the variable $F$ is important in describing the dynamics of industry profits and cooperation. ${ }^{4}$ Given the enormous costs that result from being cheated, diamantaires will only transact with individuals that have established a good reputation. And because one's reputation is reflected in past dealings, even a well-intentioned merchant will not earn the trust of other merchants. For this reason, the industry has relied heavily on family businesses, in which established merchants bequeath their reputations to their progeny (this also solves an end-game problem by inducing retiring merchants to keep promises through their last transaction). Thus, entry is largely limited to the descendants of current merchants. The few merchants who manage to enter without family sponsorship toil for many years in low-level positions before slowly earning the trust of their peers.

If Equations (1) and (2) constitute the general requirements for sustaining multilateral cooperation for Klein \& Leffler's manufacturers, a slight modification is necessary to adapt the framework to diamantaires. Diamantaires on 47th Street are intermediaries along a long distribution chain, one that originates with miners of rough diamonds and ends with jewelry manufacturers (Richman 2006). Unlike manufacturers that select a technology with a fixed cost $\mathcal{c}_{\mathrm{h}}$, diamantaires costs are a function of the wholesale prices of diamonds $\left(p_{\mathrm{w}}\right)$, which is determined by producers (miners) and varies with market conditions. And their revenues are functions of the retail price $\left(p_{\mathrm{r}}\right)$, which represents the endogenous market retail price that diamantaires sell to jewelry manufacturers. For simplicity, let the collective

4 Klein \& Leffler (1981) suggest that the sunk costs that sustain incumbents but close the markets to potential entrants could include brand name capital investments, nonsalvageable productive assets, or advertising. Some of these conceptually overlap with investments in reputations, and construing $F$ as the costs of building a credible reputation fits in with the Klein \& Leffler framework. 
profit for a cooperative (i.e. mutually honest) trade between two diamantaires be $\pi=\left(p_{\mathbf{r}}-p_{\mathrm{w}}\right)$. Retaining the other features of the Milgrom, North, \& Weingast (1990) and Klein \& Leffler yields updated Equations (1) and (2) as follows:

$$
\begin{gathered}
{\left[\left(\left(p_{\mathrm{r}}-p_{\mathrm{w}}\right) / 2\right)-Q\right] /(1-\delta) \geq \alpha .} \\
\left(p_{\mathrm{r}}-p_{\mathrm{w}}\right) /(1-\delta)=F
\end{gathered}
$$

\subsection{The Comparative Statics of Reputation Mechanisms}

Equations (3) and (4) depict the conditions and constraints for cooperation in the diamond industry, and they offer a window into understanding how changes in certain economic variables will affect the profitability, and thus robustness, of sustained cooperation. Recall that $\alpha$ represents the economic return from cheating one time and is the parameter that must be overcome during each period for cooperation to continue. Since cheating in any diamond transaction remains very lucrative throughout the industry's history, $\alpha$ can be treated as a constant. Thus, to determine how changes in value to the other variables affect the sustainability of cooperation, those changes can be measured against a fixed $\alpha$.

Specifically, Equation (3) suggests that cooperation would weaken from:

- an increase in $p_{\mathrm{w}}$ (the prices diamantaires pay for rough diamonds),

- an increase in $Q$ (the costs diamantaires pay to acquire reputational information),

- a decrease in $p_{\mathrm{r}}$ (the prices diamantaires charge to jewelry retailers),

- a decrease in $\delta$ (the amount diamantaires value future cooperation).

And Equation (4) suggests that cooperation would weaken from:

- a decrease in $F$ (the cost of entering, or the size of the entry barrier to, the diamantaires market).

Although diamantaires have managed to sustain cooperation in a thirty-billiondollar industry, despite both the unavailability of court enforcement and extraordinarily lucrative temptations to cheat each other, an economic calculus suggests that cooperation will only continue if the profits from maintaining good reputations outweigh temptations to defect. Specifically, changes in the above parameters - representing sales prices, input costs, entry barriers, and other institutional features - will affect the profitability and thus the durability of cooperation. In fact, economic and political changes since the turn of the millennia have changed some of these parameters and have thus strained the cooperative equilibrium. 


\section{DISRUPTION IN PRODUCTION AND DE BEERS' CHANGING STRATEGY}

Writing about De Beers' approach to the year 2000, a Harvard Business School case study observed:

De Beers was accustomed to chaos. The company thrived on it, and had long ago learned to master it. But the millennium posed new challenges - serious challenges with the potential to undermine De Beers's legendary power and compel a rethinking of its strategy (Spar 2000, p. 2).

The accustomed "chaos" is the vicissitudes of a volatile commodities market combined with the demand elasticity of luxury goods, and De Beers' success rested on its ability to assert control throughout diamond market. For nearly a century, De Beers enjoyed monopoly control over the sale and distribution of rough diamonds. It either owned or secured exclusive contracts with a majority of the world's mining interests, and through its central selling organization (CSO) it distributed its supplies deliberately through "sightholders," a collection of approximately 125 carefully selected distributors chosen to receive and purchase caches of De Beers rough diamonds ten times each year. Sitting atop the diamond distribution chain, De Beers was able to control global supply of rough diamonds by carefully controlling what was sold each year, and it invested in sustaining global demand through creative advertising strategies and directing distribution chains. Whenever additional sources of rough diamonds threatened to enter the market, De Beers swiftly entered into exclusive purchasing arrangements with the new suppliers (Spar 2000 , p. 5). Whenever supply began to exceed demand and threatened to dampen market prices for polished diamonds, the company would show its determination to be a buyer of last resort, stockpiling rough gems to sustain stable prices (Spar 2000, 5, 9-10).

In the late 1990s, however, this decades-old strategy started to fray, and changes to diamond supply "began to hint at a very different structure for the world's diamond market and ... De Beers" (Spar 2000, p. 9). Diamond mines discovered in Australia in the 1980s and in Canada in the 1990s began resisting De Beers' control and started selling rough diamonds outside De Beers' CSO in 1996; De Beers' agreement to purchase Russia's enormous production, formed in 1990 during Russia's desperate need for hard currency, expired in 1995, and, after a year of Russian diamonds "leaking" into the global market, the Russian company Alrosa began distributing Russian diamonds independently of the CSO in 1996; Lev Leviev, an Uzbekistan-born Israeli diamantaire began developing independent diamond distribution networks from Angolan 
and Russian sources in 1997; and rough diamonds were trickling into the global marketplace from war-torn Angola and Sierra Leone (see e.g. Spar 2000, p. 9).

De Beers first responded to these new entrants with its traditional strategy of stockpiling rough gems and controlling global supply (Spar 2000, pp. 10-11), and its inventory expanded in the 1990s from under $\$ 3$ billion to nearly $\$ 5$ billion, or 100 percent of the company's annual sales (Spar 2000, p. 22). But the new sources of competition severely diminished De Beers' dominance. Whereas De Beers and its CSO controlled over 80 percent of diamond supply as recently as 1989 , its market share of rough production has since declined steadily (see Figure 1). The company simply could not sustain its historic degree of control over global production, and to the degree it sustained prices by maintaining large stockpiles, it was benefitting its competitors as much as itself. De Beers' directors recognized it needed to abandon its century-old business model.

\subsection{De Beers New Strategy}

In 1998, Nicky Oppenheim-grandson of Ernest and son of Harry, the two preceding leaders of De Beers - was installed as chief executive as part of a new management team, and the new leadership retained Bain and Company to conduct a wide-ranging strategic review (Nicky Oppenheimer later told an HBS case writer, "For any company that is long lived, there comes a time where you have to change, and cast your skin off' (Spar 2000, p. 10)). The company Nicky inherited not only competed in a different competitive environment from the one in which his father's company dominated, but it also exhibited a radically different governance structure. Before Nicky's team took over, De Beers and its sister company Anglo American were integrated through a series of complex crossholdings with both companies closely held by the Oppenheimer family (the unwiedly structure was originally designed to cushion both companies from the political hazards of cooperating with South Africa's apartheid regime, and then from the hazards of the regime's end). As the new management team took its place, the two companies spun off into separate firms. The reorganization consolidated all diamond-related industry assets and expertise into a fully integrated De Beers, with Anglo American focusing on other mining interests.

The reorganization prompted a dramatic shift in corporate strategy: Rather than being the industry's buyer of last resort, De Beers would position itself as an aggressive competitor in an increasingly crowded luxury goods market. In early 2000, the company announced that it would sell off its stockpiles and would directly enter the diamond retail market (see e.g. Richman 2009a, pp. 42-43). It forged a partnership with luxury goods company Moet Hennessey 
Figure 1. De Beers declining market share over time.

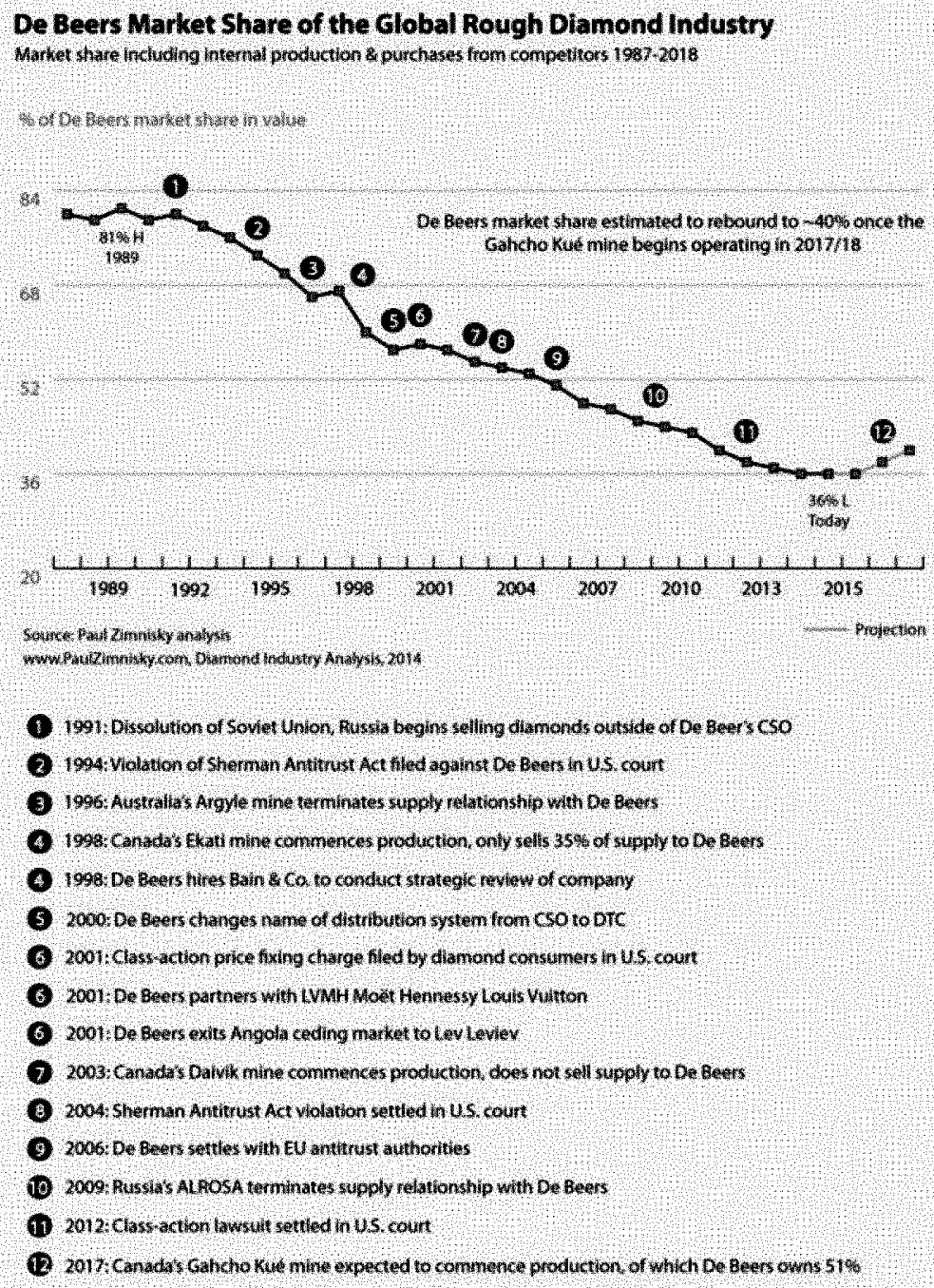

Source: Zimnisky (2014).

Luis Vuitton, developed a ring box with a logo that models a Tiffany's-like luxury style, and established a retail store in Manhattan. ${ }^{5}$ And it revealed a new

5 This required De Beers to settle all outstanding antitrust convictions with the U.S. Department of Justice, which included a 1994 suit brought by the Justice Department that accused De Beers of conspiring with General Electric for fixing the prices of industrial diamonds, and a series of private 
marketing strategy to promote the De Beers brand, abandoning its wildly successful slogan "A Diamond is Forever" for "Less than 1\% of the world's diamonds are eligible to become a Forevermark diamond." The company is thus channeling its advertising might toward stimulating sales of De Beers diamonds rather than of all diamonds. Rather than supporting the entire industry, De Beers' core strategy became to make itself distinct from the rest of the industry.

\subsection{Consequences of Changes in Production (Higher Wholesale Prices, $\boldsymbol{p}_{w}$ )}

De Beers now produces approximately 35 percent of the world's rough diamonds by value (around 25 percent by volume), with Alrosa (Russia's production company) controlling approximately 30 percent ( 27 percent by volume), and three other competitors each producing between 2 and 10 percent (Bain \& Co., Inc. 2015, p. 10). One might expect that because diamond production is no longer dominated by a monopolist and now involves several smaller players, diamond prices would be less stable and would sway with the vicissitudes of speculation and demand. Since the economic downturn of 2009, however, diamond prices have remained stable compared with other precious commodities (see Figure 2).

Theory would also predict that a less concentrated market would yield lower wholesale prices and lower monopoly rents, but here too the opposite has occurred. As De Beers' market share declined since the turn of the millennia, average prices per carat, for both rough and polished diamonds, have increased (see Figure 3), and average operating margins among leading diamond producers have also remained high, even after the global downturn in 2009 (see Figure 4).

How has the diamond industry retained (and in some cases, amplified) monopolistic features even after the decline of De Beers' notorious monopoly? ${ }^{6}$ Longtime industry watchdog Chaim Even-Zohar suggests that the diamond oligopoly is mimicking many of the pricing behaviors of the De Beers monopoly, in part due to collusion (Even-Zohar 2015). He notes that following each

class actions in 2001 that accused De Beers of manipulating the price of diamonds for 60 years. De Beers decided in 2004 to plead guilty to the government charges so it could reenter the US market and so its officers could travel to the US without arrest, and it similarly settled the class action in 2006, trying to - as a De Beers spokesperson said_ "normalize" the company's business in America. Only because these suits were settled could chairman Nikky Oppenheimer enter into the United States without fearing arrest.

6 The current Herfindahl-Hirschman Index (HHI), a common measure of market concentration and monopoly pricing power, currently is approximately 2400 for diamond production, about the same as the U.S. market for breakfast cereal. When De Beers enjoyed an 82 percent market share, the HHI was over 6700. If classic economic theory were at work, the current market structure is unable to explain the persistence of high wholesale prices. 
Figure 2. Relative price changes in diamonds vs. other commodities, 2009-2014. Inflation is represented by the U.S. Consumer Price Index; price index for polished diamond stracks stones of different sizes.



Source: Bain \& Co. (2014, p. 22). Used with permission from Bain \& Company, www.bain. com.

Figure 3. Rough and polished diamond price changes, 2004-2014.

CAGR = compound annual growth rate. Polished-diamond price index and rough diamond price index both calibrated to $2004=100$.

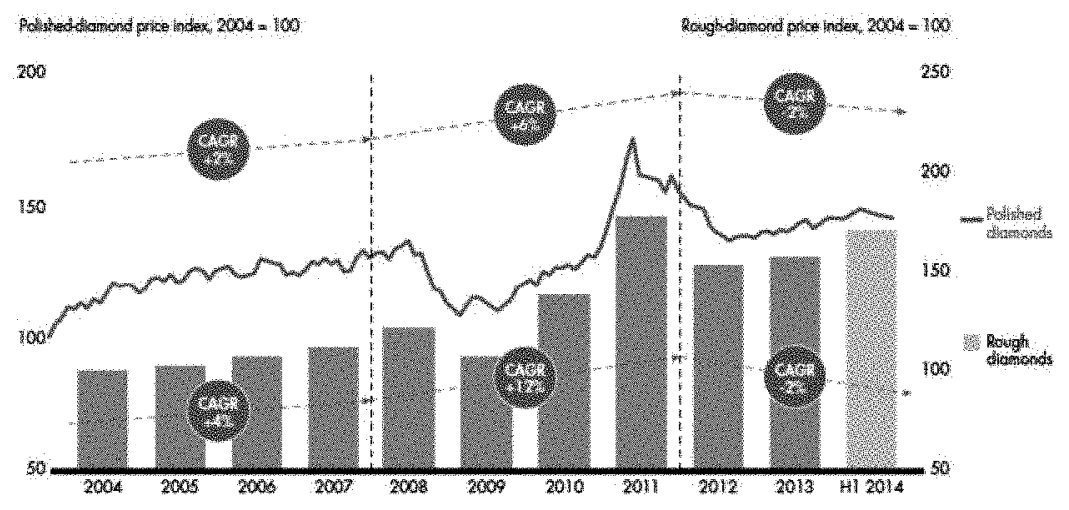

Source: Bain \& Co. (2014, p. 5). Used with permission from Bain \& Company, www.bain. com.

sight, detailed lists are distributed by DTC brokers revealing the price and composition of each purchased box of diamonds, with the intent of signaling prices for other producers (Even-Zohar 2015). Even-Zohar further points to instances in which the competing oligopolist producers have found ways to 
Figure 4. Operating margins for leading diamond producers, 2010-2014.

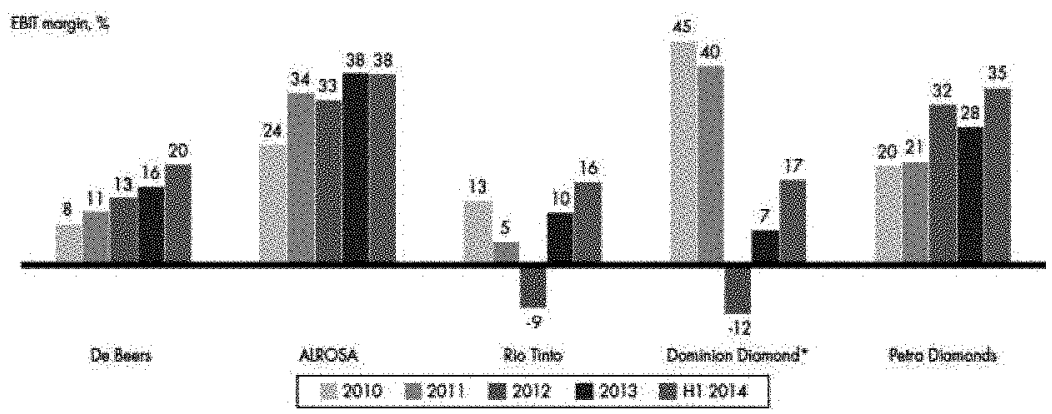

Source: Bain \& Co. (2014, p. 5). Used with permission from Bain \& Company, www.bain. com.

meet in private, including through the establishment in May 2015 of the Diamond Producers Association. The Association, founded by the seven leading producers that are collectively responsible for about 80 percent of global production, purportedly is to organize collective marketing efforts, sustain demand, and to counter threats of synthetic diamonds. Even-Zohar ruefully observes that, given De Beers' fraught history of antitrust violations (see e.g. Richman 2009a,b), the producers until recently "have refrained from showing too close of a cooperation" but evidently are now being less cautious (EvenZohar 2015, p. 4).

Even-Zohar warns, however, that the new oligopoly has departed from the monopoly in one very important respect: " $[\mathrm{T}]$ he diamond producers have used their oligopolistic powers to the fullest, having successfully driven up rough prices to such an unrealistic level as to actually endanger the economic sustainability of their very own clients and other midstream and downstream levels" (Even-Zohar 2015, p. 4). This admonition of "unrealistic" pricing is echoed forcefully in an anonymously drafted and widely circulated email from simplesightholder@gmail.com:

dear all,

As a sight holder who has suffered like all of you a few years of no profitable and even loosing boxes, I encourage you, at this difficult period not to take any box which doesn't have the value of at least $10 \%$ gross profit after polishing.

Please, if your future, the future of your children and the future of your diamond business is important to you. Don't agree to take the boxes. 
Don't be afraid to reject, nothing will really happen (unless some stupid sightholder will act stupidly and buy the boxes) they need our money, they need us and it is legitimate to expect a fair pricing which leaves also to our side some profit. If De Beers would make 300 million less a year in profit it would leave each of us (on average) with extra 3. Million dollars. What's bad and what's wrong in such a request??

Let's take care of our future, brothers.

I wish you all the best and I am happy to receive your comments.

Also please forward this to other sight holders.

Just a simple sightholder (simplesightholder@gmail.com)

Notice that Figure 3 supports this charge, showing that the price margin between rough and polished diamonds has narrowed since 2007.

It seems that the most consequential change stemming from De Beers transformation is not the company's loss of market share or the market's change from a centralized monopoly to an oligopoly. Rather, the most impactful change has come from De Beers' corporate reorientation. It no longer is a monopolist atop a distribution chain that relies on intermediaries to connect with consumers. It now sees itself as an aggressive competitor in a crowded market for luxury goods that brands its gems and strives to connect directly with affluent customers.

De Beers' entry into the retail market reflects this new orientation and illustrates a sharp contrast to the company's longtime use of sightholders. The company now dedicates many of its rough stones to produce De Beers-branded diamonds for retail sale, aiming to be a leader in luxury goods markets and refining its product lines to meet the demands of high-end consumers. It has opted for a vertically integrated strategy in which it controls every stage of a diamond's preparation for retail sale. De Beers consequently is less reliant on seasoned diamond dealers to provide market information and direct diamonds to valuable targets and thus no longer aims to support an entire industry and its network of middlemen. To the contrary, many of these middlemen are now De Beers competitors. The diamond value chain no longer reflects the longterm collaboration between De Beers and its sightholders-between upstream suppliers and downstream distributors - and the company's relationship with these intermediaries has turned from collaboration to competition.

In fact, De Beers' vertically integrated strategies help explain some curiosities of the prior strategy. Economic theory implies that an upstream monopolist maximizes profit when downstream markets are competitive. Yet De Beers, in contrast to theory, sold only to handpicked dealers. Moreover, and similarly in contrast to theory, diamond merchants have clamored to become a sightholder 
atop the distribution stream, which suggests that De Beers sells diamonds to sightholders at less than the monopoly price and instead shares with them some monopoly rents. The reason for De Beers' curious distribution strategy is that it relied on these merchants to ensure that rough stones were directed to their most valuable use. It therefore selected as sightholders merchants who were deeply familiar with the diamond trade to know how to cut, distribute, and market diamonds to create maximum value. In short, De Beers relied on downstream merchants' market information and industry expertise, and the company implemented a pricing strategy that economically sustained these knowledgeable intermediaries.

The industry's longtime intermediaries - especially mid-size and small operators who do not partner with leading retail chains-are both the primary victims of this new pricing strategy and the most vulnerable. Compared with the upstream production and downstream retail markets, this intermediate market for distributing and cutting rough diamonds has long offered the slimmest margins (see Figure 5), and producers' pricing efforts have caused these margins to continue to shrink. Consequently, De Beers' new strategy has had major reverberations throughout the diamond distribution chain.

\section{INNOVATION AND SEGMENTATION IN RETAIL (LOWER RETAIL PRICES, $p_{r}$ )}

A Forbes article entitled "Romance Killer" describes Mark Vadon, founder and $\mathrm{CEO}$ of Blue Nile, as "an unlikely party crasher in a business dominated by multigenerational family firms led by Orthodox Jews” (Murphy 2004). Blue

Figure 5. Profit margins for different stages of the diamond chain.

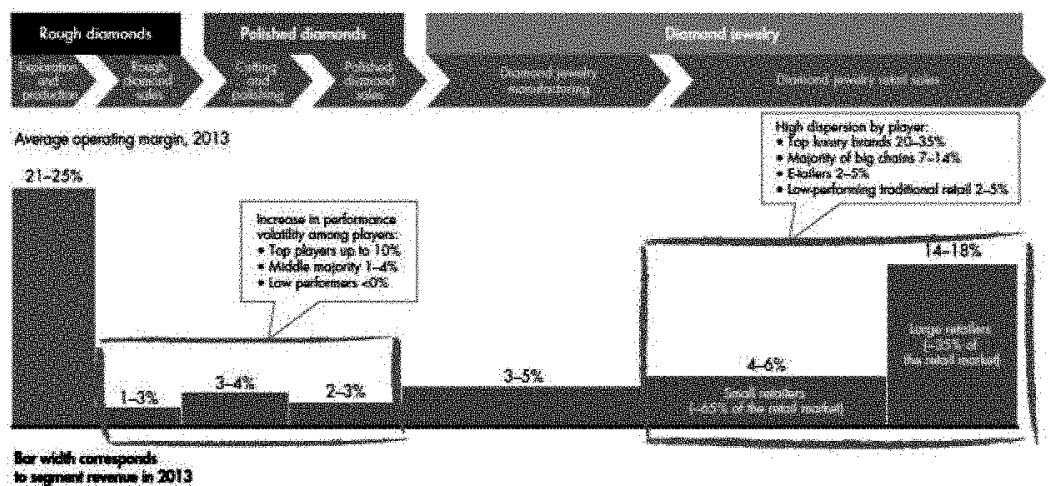

Source: Bain \& Co. (2014, p. 6). Used with permission from Bain \& Company, www.bain. com. 
Nile, founded in 1999 as part of the Internet retail boom, is the world's pioneer in internet diamond sales. The company serves as an exchange between consumers and diamond dealers, in which dealers describe the attributes of each stone-Carat, Cut, Color, and Clarity (the 4Cs) - in accordance with standardized GIA metrics. Each stone has a GIA certificate confirming its metrics, and consumers can compare stones by price and quality (Murphy 2004).

Blue Nile is no longer a lone force in Internet diamond retail, having been joined by Amazon, AliBaba, eBay, and other Internet sites. Internet retailers constitute 13 percent of America's total jewelry sales, and although Internet sales are not apparently growing faster than bricks and mortar retail sales, they are having a lasting impact on the diamond value chain by introducing transparency to diamond pricing (Shnidman 2013). Bringing price transparency was key to Vadon's retail strategy (Forbes reported that "Mark Vadon believes diamonds are just pork bellies waiting to happen,") but it is anathema to an industry that relies on mystique, heavy markups, and careful in-person inspection (Murphy 2004).

The rise of Internet retail has had only a modest effect on large, high-end stones, and it appears that high-end diamond retail markets remain distinct from the Internet market. This is likely because luxury retail services provide valuable complementarities to high value stones - the expertise displayed by the salesperson, the elite brand, the cozy retail space-and accordingly, very few large stones are sold by Internet retailers. But Internet sales have put meaningful downward pressure on prices for midsize and small polished stones. While prices for large, high-quality stones rose significantly over the past decade, prices for smaller and midsize polished gems were nearly stagnant (see Figure 6). The new price pressures have eliminated many of the margins that diamond dealers enjoyed as intermediaries, and the gap between rough prices and polished prices (for all but the largest stones) continues to narrow.

Internet retailers have done more than introduce price information and squeeze profits. They also have challenged many core foundations on which the diamond industry has traditionally relied. Forbes, for example, colorfully illustrates how Internet retail's emphasis on price comparisons is in tension with many forces that traditionally fueled the industry:

Vadon's success rankles many in the diamond trade. Some wholesalers won't deal with him; some retailers refuse to order from those who do. One trade group recently advised jewelers to sell their engagement rings at a loss to blunt Blue Niles' inroads ... "We try not to sell diamonds as commodities," adds Jonathan Bridge of the 74-store Ben Bridge jewelry chain in Seattle, which has been peddling stones for 92 years. 'Every diamond is different. There's a certain amount of romance to that.' (Murphy 2004) 
Figure 6. Price changes for polished diamond, by gem size and quality, in volume and value, 2003-2013. RDI = Rappaport Diamond Index, reflecting average per carat diamond prices. D-IF = diamonds of color D (colorless) and clarity IF (internally flawless), the highest diamond grades.

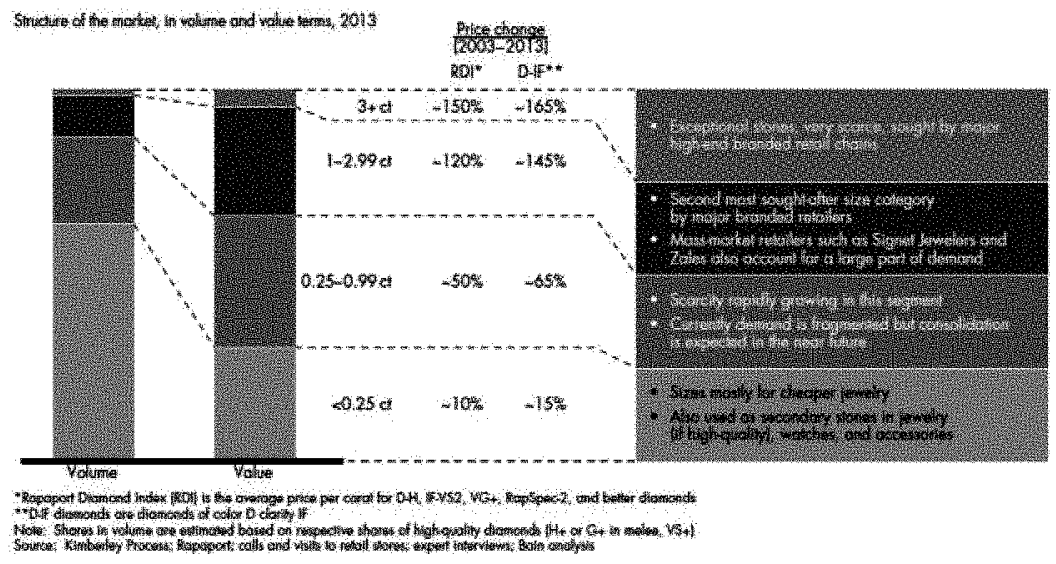

Source: Bain \& Co. (2014, p. 27). Used with permission from Bain \& Company, www.bain. com.

But Forbes is unsympathetic: "Blue Nile is creating a race to the bottom,' complains Alan Rehs, a wholesaler and cutter in New York. "This is bad for the industry.' He says customers walk into stores brandishing Blue Nile printouts as bargaining chips. Horrors" (Murphy 2004).

Internet sales and its ushering of transparency have introduced an even more significant disruption to the diamond distribution chain. Previously, intermediaries were relied upon to direct stones to their highest value use, matching individual stones with purchasers who would pay the most. These seasoned diamantaires utilized their own market information and the information asymmetries they enjoyed over outsiders to channel stones toward purchasers who would yield additional margins. Their market information both provided a key step in the value chain and secured their profitable role within it. Now, that market information is more widely available. Price transparency has not just introduced new price pressures, but it has obviated much of the value that intermediaries historically provided.

\section{ENTRY AND DISRUPTION TO DIAMOND INTERMEDIARIES (LOWER ENTRY BARRIERS, F)}

Diamond dealers, as intermediaries between rough producers and purchasers of polished stones, have thus suffered twin pressures since 2000. Diamond 
producers have increasingly aimed to extract higher prices in rough diamond sales, and Internet retailers have introduced downward price pressures for many polished diamonds. Both of these developments have diminished available margins for intermediary diamantaires and they correspondingly have diminished the incentives to sustaining strong reputations in the trade. Yet while these developments occurred in the production and retail markets, even more dramatic developments took place in the intermediate stage of sorting, cutting, and brokering diamonds.

Until the mid-1970s, the diamond industry was dominated by a tightly insular network of predominately Jewish merchants. The global diamond trade was concentrated in Jewish strongholds in Antwerp, Israel, and New York, and ethnic homogeneity was an industry hallmark. However, as international trade became more fluid, opening up both production and consumer markets in an increasingly globalized economy, new diamond merchants entered the trade and the industry's profile began to change.

The first new arrivals came from a diffident community of merchants from a small town in Gujarat, India. These Palanpuri Jains (Jainism is a religion, Palanpur is a town in Gujarat) had a history in the diamond industry that reached back at least to the 1880s, and by World War II many had constructed family networks that acquired rough diamond supply in Antwerp, orchestrated diamond cutting in Gujarat, and sold polished diamonds in New York and other retail centers (Hofmeester 2013, pp. 44-47). But starting in the 1970s, Palanpuri families started entering the industry en masse and triggered what was likely the most significant development in the diamond industry since the discovery of South African diamond mines a century ago. When Australia's Argyle mines created a production boom in 1979, Palanpuri families dramatically expanded their operations, setting up thousands of cutting factories in Gujarat (Munshi 2011, p. 1085), and by 2000, the majority of the world's diamonds were cut in India, making the country perhaps the most important diamond capital in the world (see Richman 2006, pp. 410-411; Hofmeester 2013, pp. 44-47).

Although the rapid expansion of India's diamond industry was fueled primarily by Palanpuris, other ethnicities also entered the sector. Many Marwaris, India's traditional traders and bankers, joined Palanpuris as owners of diamond firms, and both Marwaris and Palanpuris mostly employed local Kathiawaris, who were predominantly farmers who migrated to Gujarat's urban and industrial centers when work became available in Jain-owned cutting factories (Shor 1993). This influx of new Indian family businesses into the web of diamond intermediaries not only transformed the profile of the diamond trade but significantly changed the economics. The introduction of new intermediary networks made this segment of the industry more competitive and 
correspondingly caused margins to decline. But several aspects about the nature of this entry put additional strains both on the industry's norms for cooperation and the incentives to sustain cooperation.

In time, Kathiawaris grew from factory workers to factory owners, and Kathiawari families currently control over 50 percent of the diamond trade in Gujarat's capital Surat (Khanna 2008; Shah 2008). But Kathiawari entrepreneurs were meaningfully different from their Palanpuri and Marwari counterparts. According to a 2011 study by Cambridge economist Kaivan Munshi, Kathiawari diamond merchants were younger, had fewer years of education, were less likely to be schooled in English, and were more likely to be raised far from urban centers (Munshi 2011, p. 1081). More significant, especially for the diamond trade, only 35 percent of sampled Kathiawari diamantaires compared with 82 percent of Palanpuris and 76 percent of Marwaris, reported that their father was engaged in any type of business (Munshi 2011, p. 1082). Additionally, the percent of Kathiawari entrepreneurs entering the diamond industry with businessmen fathers declined significantly from 1980 to 2000, whereas the percent for entering Palanpuris and Marwaris largely stayed the same (see Figure 7; Munshi 2011, pp. 1089-1091). For an industry that relies on

Figure 7. Family background of entering entrepreneurs in India's diamond industry (Munshi 2011, p. 1090).

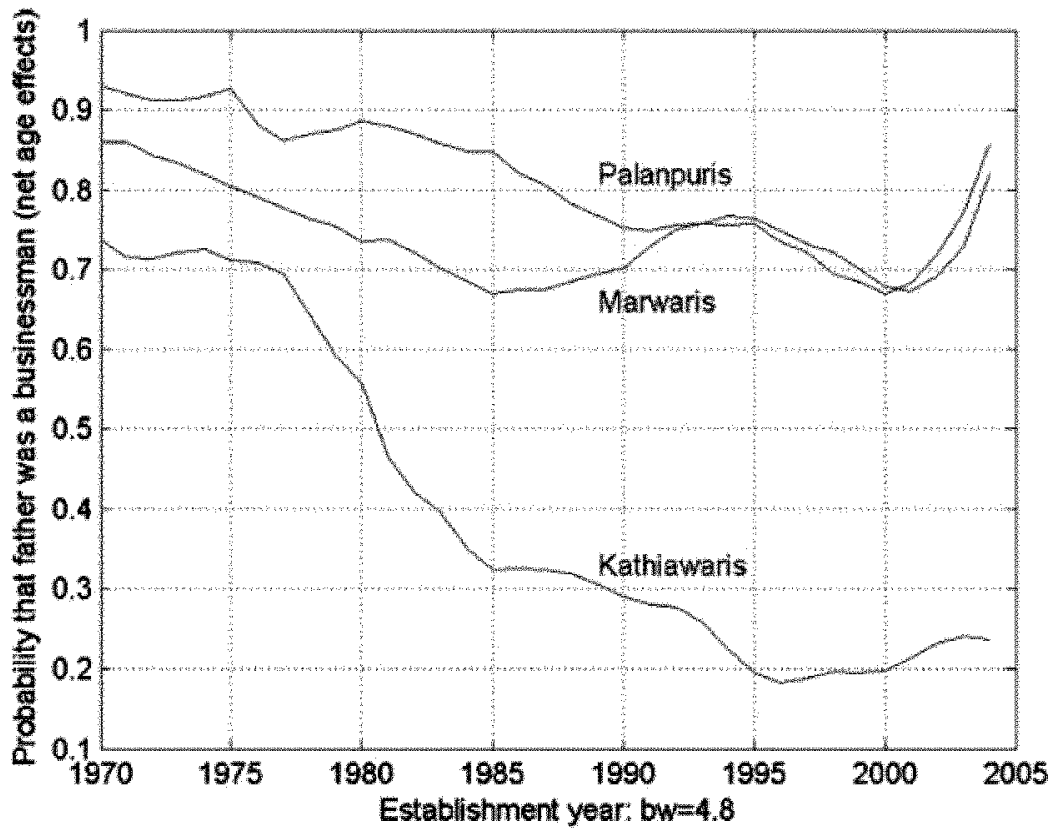


intergenerational business to sustain longterm cooperation, the entry of Kathiawaris introduced an unfamiliar kind of entrepreneur.

Indian banking policies have further fueled the entry of non-traditional business families into the industry. To encourage exports, the Indian government requires local banks to earmark a percentage of their credit to finance exporters (Golan 2013, p. 106; Reserve Bank of India 2013). This financing is especially attractive to borrowers because it must be offered at a reduced rate and in U.S. dollars. Since gems and jewellery are India's second largest export and constitute approximately 14 percent of all Indian exports (and nearly 7 percent of India's GDP) (India Brand Equity Foundation), Indian banks - led by the Bank of India-found eager borrowers in the diamond sector (Ashreena \& Ananthalakshmi 2015).

Even when Indian diamond firms are reliably lucrative and thus generally safe bets for banks, financing diamond operations is notoriously difficult to govern, and so the policies encouraging bank loans to diamantaires introduced a number of hazards. First, because diamonds are difficult to identify individually, unlike a car or real property, diamantaires were able to take out multiple loans for a single bundle of diamonds. Second, because diamonds are difficult to value accurately, especially by non-diamantaire bankers, diamond companies were able to borrow sums that exceeded the actual value of the diamonds they used for collateral. Finally, the loan subsidies encouraged entrepreneurs with diamond companies to use subsidized loans for non-diamond purposes, or even to reloan the borrowed money at market prices. These difficulties illustrate why most diamantaires get their financing in the form of credit sales from fellow diamantaires who understand the business, are well equipped to value stones, and are more practiced at assessing the associated risks.

These Indian bank policies, some of which were mimicked by banks outside India, encouraged banks to invest in the burgeoning diamond sector. They extended generous lines of credit to diamond dealers and factory owners for the purchase of rough stones without the ability to manage the associated risks. They also caused the Indian diamond sector to grievously overextend itself. Outstanding debt belonging to diamond intermediaries grew from $\$ 7$ billion in 2002 to about $\$ 16$ billion in 2013 , with 40 percent of the entire global industry's banking debt now owed by Indian firms (Bain \& Co., Inc. 2014, 39, 43). Predictably, many are now insolvent, financing is drying up, and the spread of bad loans have destabilized the sector. A former chairman of India's Gem \& Jewellery Export Promotion Council recently lamented:

The rash of bankruptcies among diamond processing companies today isn't simply bad news for these companies and their creditors. It's bad news for all of us. The banks don't trust the industry any more, and 
today, even legitimate, well-run companies are being regarded with suspicion and are facing sharply tightened lines of credit (Kothari 2015).

In sum, the intermediaries - the dealers, cutters, and brokers-that traditionally directed diamonds from De Beers and other producers to jewelry manufacturers have watched their industry segment transform enormously in the past 30 years. They entered the diamond trade when entry barriers were reduced-when globalization opened India's entrepreneurs and production capabilities to the world, and when India's generous credit policies subsidized new entry. The rise of Indian merchants greatly expanded competition, reduced margins, and even fueled financial improprieties, all of which introduced new financial pressures even to scrupulous businesses. These structural challenges to the intermediary segment of the value chain were well underway by 2000 , when De Beers' started pricing more aggressively and when Internet retail placed downward pressures on prices for polished diamonds.

\section{THE EROSION OF TRUST AND THE RISE OF VERTICAL INTEGRATION}

Until recently, the diamond industry has been known for sustaining trust-based exchange, and the foundations of that sustained cooperation rested upon the promised rewards of sustained cooperation, including the promise of reliable profits to bequeath to subsequent generations. However, these diamantaires now see diminishing payoffs from cooperation, and simple game theory-reflected in Milgrom, North, \& Weingast (1990) and Klein \& Leffler (1981) illustrates why reports from industry insiders, the trade press, and 47 th Street merchants reveal a breakdown of a cooperation. And because DDC officers and arbitrators are dealers themselves who also have experienced diminishing payoffs, these industry leaders have become more short-sighted and less trustworthy, thus undermining the institutions designed to police merchants and facilitate cooperation. In short, structural changes in the global diamond market, introduced by changes in geopolitics, industry structure, and technology, have changed the payoffs to cooperation, and this explains its industrywide erosion.

Because the diamond industry has been held out to be the paradigm for trustbased exchange, both by the popular press and by an especially significant number of important scholars, an end to its sustained cooperation requires reassessing earlier understandings. This final section, aiming to derive lessons from the autopsy of cooperation, discusses some academic debates and prevailing theories that now require revisiting. 


\subsection{The "Institutional Life Cycle" of Cooperation (Lower Valuations of the Future, $\delta$ )}

The diamond industry clearly was, for a time, characterized by trust-based exchange. But does its erosion of trust mean that it was previously misunderstood, or is there a unifying theory that can explain how sustained cooperation breaks down? Perhaps instead of designating the diamond industry as a paradigm for cooperation and mutual trust, its rise and fall of trust-based exchange might instead fit into a broader phenomenon.

Although this erosion of cooperation pierces the diamond trade's conventional narrative, it has some historical analogs. Economic historian Avner Grief offers several examples of what he calls the "institutional life cycle," in which institutions that emerge to sustain cooperation eventually sow the seeds of their own demise (Grief 2006, p. 176). Genoa, for example, was a thriving commercial center in the 11th century primarily due to the mutual interdependence and cooperation between its ruling commercial clans; yet the success of these clans generated such wealth that control of the city offered a reward that overwhelmed the certain shared gains from continued cooperation (Grief 2006, pp. 217-268). Once a German emperor, who had presented a common enemy to the clans, no longer posed a military threat, the clans battled for complete control of the city and abandoned productive cooperation (Grief 2006, p. 176). Similarly, the merchant guilds of the twelfth and thirteenth centuries orchestrated self-enforcing multilateral reputation mechanisms that brought wealth to both merchants and their supportive rulers (Grief 2006, pp. 91-123), but this success led to an expansion of trade that stretched the limits of reputation mechanisms and diminished the value to the crown to protect the marginal merchant from expropriation or unfair dealing. Eventually, peripheral traders could not rely on fair dealing, and trust broke down throughout the merchant populations (Grief 2006, pp. 91-123). And the institutions that Grief calls the "Community Responsibility System," which enabled impersonal intercommunity exchange in the thirteenth and fourteenth centuries, also became victims of their own success. These cooperative arrangements had local authorities commit to punishing local residents who cheated foreigners in exchange for a commitment from distant authorities to reciprocally punished their own (see e.g. Grief 2006, pp. 309-349). But, Grief explains, "[g] rowth in the number of traders and communities, the locations of trade, and intercommunity interactions reduces the cost of falsifying one's community affiliation and increases the cost of verifying one's identity" (Grief 2006, p. 338). Their growth also led to their demise.

It could similarly be said that diamantaires have been a victim of their own success. The lucrative opportunities as an intermediary attracted entry from ethnic networks and family businesses who were able to manage the diamond 
value chain. As the industry grew, it became more diverse, and the mechanisms that were historically relied upon to secure credible commitments-the prospect of bequeathing valuable reputations to the next generation-were not as effective. In a similar fashion, the industry amassed political power as it grew, enabling it to extract new and untraditional sources of financing, which inadvertently undermined the industry's historical mechanism of securing credit and punishing defaulters. When production and retail markets changed because of exogenous geopolitical and technological changes, the thinning incentives to sustain cooperation were overwhelmed.

Another feature of the industry's success has been the diamantaires affluence and thus acceptance into mainstream society. Whereas Amsterdam's and Antwerp's diamantaires in the late nineteenth and early twentieth centuries, most of whom were Jewish, always remained isolated and distinct from the dominant cultures, Jewish, Indian, and middle eastern diamantaires have fully integrated into the cultural polyglots that house the twenty-first century's diamond centers. With acceptance comes acculturation, and thus greater choices and economic opportunities, and many diamond merchants-like the Antwerp merchant interviewed in 2013, discussed above (Richman 2013) - have seen their children select different occupational paths. Intergenerational businesses and the forces that sustain the value of an honest reputation are central in supporting cooperation, and the diminishing presence of children in family businesses meaningfully erodes the merchants' incentives to cooperate longterm.

Grief's historical lessons teach that trust can break down even when only marginal merchants can no longer rely on credible commitments to punish wrongdoing and reward cooperative behavior. It recalls what a diamond merchant told Shor: "Even if one percent of the dealers were dishonest, that trust would be destroyed and so would our industry" (Shor 1993). Mathematically, this is captured by a diminishing valuation of future cooperation, denoted in parameter $\delta$. Once some diamantaires begin cheating, then the industry's overall credibility erodes, and the expected rewards from maintaining a trustworthy reputation decline. Indeed, a growing percentage of New York's and Antwerp's diamond merchants are seeing their children pursue careers outside the industry.

\subsection{The Failure of a Reputation Mechanism (Higher Costs to Acquire Reputational} Information, Q): Vertical Integration and the Institutional Economics of the Diamond Chain

It was noted in the introduction that the very institutions designed to secure the industry's reputation mechanism have become less credible. One simple reason 
is because the individuals at the helm of the industry's organizations-the DDC's leadership and arbitrators-are seeing diminishing returns themselves from honest conduct. But as these institutions fail to provide accurate reputational information, they also accelerate the deterioration of industry-wide cooperation. This is captured by an increase in $Q$, the cost assumed by individual merchants each transaction to acquire accurate information about their trading partner. As the industry's informational mechanisms lose credibility, merchants lose their cost-effective sources of reputational information, which in turn imposes a cost to pursuing honest conduct.

It is unsurprising that a failure of the industry's central organizations would coincide with a deterioration of industry-wide cooperation. What is more important is how purchasers and sellers of diamonds will respond to a breakdown in the reliability of the industry's traditional middlemen. Unless a cooperative equilibrium is restored-and lessons from history teach that once trust is lost, it is very hard to recover - the diamond industry will undergo dramatic structural changes. The breakdown of trust-based networks and the erosion of a reliable distribution network from producers to jewelers will force jewelry manufacturers will seek alternative mechanisms to procure diamonds. Interestingly, it also means economists will have to reassess their understanding of the economics of the diamond chain.

The diamond chain attracted scholarly attention from some pioneering organizational economists, and their early work put De Beers' method of block booking - its practice of selling prepackaged caches of heterogeneous rough diamonds for a single take-it-or-leave-it price-within the cannon of institutional economics. Yoram Barzel, writing in 1977, argued that De Beers uses block booking to economize on measurement costs. "Had the contents of a particular bag been available for appraisal by all buyers," Barzel explained:

[E] ach would have spent resources to determine the properties of the diamonds.... The incentive for De Beers to engage in this peculiar form of trade seems to be that buyers are now in a position to spend on the actual purchase of the diamonds the amount they otherwise might have spent on collecting information" (Barzel 1977, 304-305).

In other words, because buyers were spared the costs of evaluating individual stones, they were willing to pay De Beers more for the average stone.

Roy Kenny and Benjamin Klein, writing in 1983, similarly observed that "a precise estimate of the value of individual rough diamonds would require costly, duplicative examination costs" (Kenney \& Klein 1983, p. 539). De Beers engages in block booking "to prevent buyers from rejecting parts of a package of products that has been averaged priced" and in return, De Beers "pays a premium to its buyers by selling diamonds at less than (costless-search) 
market clearing prices" (Kenney \& Klein 1983, p. 506). In short, because buyers agree to purchase the entire cache, saving De Beers the additional burden remarketing rejected stones, De Beers is willing to charge less.

These related and contemporaneous analyses (despite the slight tension between them) stood as accepted wisdom for De Beers' distribution strategy. By remaining exclusively upstream, De Beers created and benefitted from the efficiencies of avoiding the duplicative and effort-intensive measurement costs of evaluating individual stones. The block booking strategy created value both by economizing on search costs and by generating the efficiencies from a dis-integrated supply chain.

Recent organizational changes to the supply chain require rethinking these conventional explanations. Most significant of these changes is De Beers' current implementation of a vertically integrated strategy (Spar 2006). Although it continues to sell some rough stones to its sightholders, it retains many stones for itself, supervises their polishing, manages their placement in jewelry setting (and ensuring their uniformity, so as to market them as identical branded stones), and sells them through their own retail stores. It also has implemented a "Supplier of Choice" program in which it enters long-term, detailed contracts with select sightholders (see e.g. Kuryan 2015). De Beers gives these chosen distributors access to De Beers' high quality stones and permission to market those stones as De Beers' "Forevermark" diamonds, and in exchange the sightholder invests in and implements specific production and marketing plans. This program binds certain distributors and retailers more closely to De Beers than any previous sightholder.

Other producers are pursuing vertical strategies as well. Rio Tinto, for example, teamed up with Chinese designers and jewelry manufacturers to use the company's Argyle mine stones to create products targeting the Chinese market (Bain \& Co., Inc. 2014, p. 21). And Alrosa has been working with Christie's and Sotheby's to market polished diamonds directly to consumers (Bain \& Co., Inc. 2014, p. 21).

Perhaps more significant, industry leaders from other segments of the distribution chain are also vertically integrating. Luxury retailer Tiffany \& Co. created a wholly owned subsidiary, Laurelton Diamonds that purchases, cuts, and polishes rough diamonds (Bain \& Co., Inc. 2014, p. 29). Laurelton has also entered into long-term contracts with De Beers, Alrosa, and Rio Tinto to procure steady supplies (see e.g. Bain \& Co., Inc. 2014, p. 31), and it has additionally contracted with smaller producers to purchase stones from individual mines (Bain \& Co., Inc. 2014, p. 29). Chinese luxury retailer Chow Tai Fook has also integrated upstream, entering long-term supply relationships with producers and operating major cutting and processing factories (see e.g. Bain \& Co., Inc. 2014, p. 17). And Signet Jewelers, owners of retail chains Zales, 
Jared, and Kay Jewelry (plus others), now operates polishing factory in Botswana (Bain \& Co., Inc. 2014, p. 17). Major wholesalers-in particular, the highest volume sightholders and purchasers from the top producers - are integrating downward as well. Although the majority of the 5,000 firms that purchase, sort, polish, and sell wholesale diamonds are dis-integrated family firms, the largest 110 firms constitute 70 percent of the wholesale market and are increasingly integrated into polishing, jewelry manufacturing, and retail sales (Bain \& Co., Inc. 2014, pp. 28-29).

These recent organizational changes - the rise of greater vertical integration across the industry and the corresponding end of the Barzel and Kinney \& Klein models (Bain \& Co., Inc. 2014; Kothari 2015) — are a direct reaction to the loss of trust-based cooperation in the industry. As retailers invest in their brands, they are increasingly vulnerable to the hazards that classically demark the diamond trade, in particular the misrepresentation of synthetic diamonds, conflict diamonds, or laser-treated diamonds as natural and unadulterated diamonds. When the disintegrated distribution system lacks the trustworthiness it historically has had, vertical integration strategies arise to mitigate these transactional hazards.

Even while this rise of vertical integration is understood as an accepted reaction to the diminishing credibility of trust-based exchange, it still presents a challenge to the explanations offered by Barzel and Kenney and Klein. Those accepted understandings of the diamond network suggested that measurement or examination costs encouraged De Beers to pursue block-booking strategies. But the loss of trust among intermediaries has no effect on measurement costs, so even if suppliers like De Beers could not trust downstream purchasers, a measurement cost explanation would mean De Beers would still resist integrating downward. ${ }^{7}$ A better explanation comes from transaction cost economics, which states that vertical integration emerges to govern exchange when marketbased organization cannot secure transactions. ${ }^{8}$ It seems that an economizing of transaction costs induced the industry to adopt the disintegrated chain for so

7 In fact, the many accounts of DeBeers business practices suggest that the company, contrary to the measurement costs explanation, did indeed invest heavily in measuring, accounting, and valuing each stone sold to sightholders. Thus, previous academic explanations do not square entirely with journalistic descriptions of DeBeers' business practices.

8 The rise of vertical integration as a response to transactional hazards, such as the loss of credible trust-based exchange, is a central prediction of transaction cost economics. See Williamson (1975). For a review of empirical studies documenting the robustness of transaction cost economics, see Shelanski \& Klein (1995) and Macher \& Richman (2008). Williamson discusses the diamond industry as an instance in which social relations secure hazardous transactions that otherwise would require governance from vertical integration, see Williamson (1993). 
many years when trust-based exchange was reliable, ${ }^{9}$ and now diminished trust has changed the transaction costs calculus. In short, the erosion of the industry's disintegrated distribution chain reveals the real economizing forces that sustained it for many decades.

\subsection{Embeddednesss, Calculativenes, and the Origins of Trust}

Structural changes in the diamond industry's distribution network also speak to a long-debated feud in economic sociology. As an archetype for trust-based exchange, the diamond industry fueled examinations over the very origin of trust and triggered one of the more seminal debates in both organizational science and institutional theory. The erosion of trust in the industry offers additional insight into that central debate.

In a famous exchange, Mark Granovetter and Oliver Williamson disputed whether economic relationships are embedded within social structure or whether they are responsive to economic forces. Granovetter argued that diamond transactions are "embedded in a close-knit community of diamond merchants who monitor one another's behavior closely" (1985, p. 492). Oliver Williamson countered that "the appearance of trust among diamond dealers is deceptive. ... [T] he organization of this market succeeded because it was able to provide cost-effective sanctions more efficiently than rivals" (Williamson 1993, pp. 471-473). In short, Granovetter argued that embedded social relationships created a framework for trust-based diamond transactions, whereas Williamson argued that diamond transactions were secured only by a credible system of punishments. To Granovetter, trust was an outgrowth of social relations. To Williamson, merchants calculated the benefits and risks of engaging in particular transactions, and what looked like "trust" - what Williamson calls "calculative trust" (Williamson 1993, p. 453) — was a market equilibrium driven by credible sanctions.

Recent changes in diamond relations seem to make Williamson the winner of this argument. The erosion of trust has occurred without any meaningful erosion in the associated Jewish or Indian communities. To the contrary, economic forces have reduced the benefits of trustworthy behavior and the economic rewards from a good reputation, and the loss of trust is much more of a consequence of calculated self-interest. In fact, Williamson observed in 1993 that changing technologies in the diamond industry revealed that "the bases for

9

Indeed, because value in the diamond chain relied on matching a particular stone with an optimal buyer-the diamond network is very much an open exchange, like stock exchanges - the incentive 
commercial trust has become more transparently calculative" (Williamson 1993, p. 473). He observed that advances in communication and other modernizations made the diamond exchange look increasingly like other markets, and he might have been anticipating the limits of social relations-and the centrality of efficiency considerations - in determining the industry's future.

Regardless of the forces that originally shaped the diamond industry's unique structure, there undeniably has been a concurrent loss of trust and a wave of vertical integration, and established theory suggests that the former is driving the latter. Perhaps more significant to economic sociologists and those studying embedded social organizations, the structural changes in the diamond industry are reshaping not just its distribution network but the face of the entire industry, from the companies involved in exploration and production to the retail chains designing and selling jewelry. And presuming trust will be difficult to restore, one can expect more vertical integration to come. Large retailers, large mining operations, and a few elite intermediaries will likely gain greater control of the diamond value chain. They will market branded diamonds and spend little effort relying on the family-oriented diamond networks that sustained the industry for a century. One might say that 47th Street is going corporate.

\section{CONCLUSION: LESSONS FROM AN AUTOPSY AND THE SUSTAINABILITY OF TRUST}

Changes in the diamond industry have not gone unnoticed-there is palpable fear that growing distrust will further erode the industry's foundations-and many industry insiders have called for immediate action to stem the snowballing of uncooperative behavior. Critics of New York's DDC hope that its new leadership will restore confidence in both the Club's management and its arbitrators (see e.g. Even-Zohar 2011). Indian diamond business leaders have urged their brethren to use state-sponsored credit more responsibly, not just to avoid overexpansion and incipient bankruptcies but also to restore traditional mechanisms to govern credit and creditworthiness (see e.g. Kothari 2015). And diamond dealers worldwide have called upon De Beers and other suppliers to price at what are called more "sustainable" and "realistic" levels, to ensure the long-term viability of the intermediaries that have been the companies’ historic partners (see e.g. Even-Zohar 2015; simplesightholder@gmail. com). Perhaps reform both among producers and the diamond dealers will stem the attrition of trust and the collapse of the historical value chain.

But if Avner Grief's historical analogies are apt and past is prologue, the industry's cooperation will continue to erode. This autopsy of the industry's 
decades of trust offers some lessons on both the economics of the diamond industry and the sustainability of trust-based exchange.

First, and most fundamentally, we have to rethink what has become the prevailing understanding of cooperation and dispute resolution in the diamond industry. Seminal works by Bernstein (1992), Shor (1993), and others describing an industry that relied on trust alone to resolve disputes and secure exchange, that could develop its own system of arbitration and did not need the supports of state-sponsored law and courts, now appear anachronistic. Revisiting that early work through the lens of history reveals they described only a temporary arrangement, that the cooperative frameworks they observed were dependent on a confluence of institutional and historical circumstances that did not sustain themselves in the longterm. Because the industry's reliance on arbitrators, privately constructed law, and reputation mechanisms has succumbed to conventional commercial relationships and legal enforcement, the efficiencies and praise accredited to those private institutions need to be reconsidered.

Second, we have to reconceptualize the economics of the diamond chain. Like Bernstein and Shor, both Barzel (1977) and Kenney \& Klein (1983) offered an understanding that became prevailing wisdom but no longer conforms with reality. The distribution system they explained through the lens of measurement costs is now being abandoned for vertically integrated strategies. These structural changes are not being triggered because measuring a diamond's qualities has become less costly (there is no evidence measurement costs have declined) but instead are due to the waning reliability of the dis-integrated distribution chain. Those earlier works did not appreciate how much the distribution structure had relied on trust-based exchange among intermediaries, and the loss of credible reputation mechanisms along the supply chain has caused the distribution structure to change. In short, our economic understanding of the diamond industry-like our legal understanding-only improves when historical changes pose new challenges to prior beliefs.

Third, consistent with transaction cost economics, we observe how trustbased relationships and vertical integration are substitutes for each other, and that vertical integration takes hold when trust breaks down. In fact, given that each diamond transaction presents a significant governance challenge, and that vertical integration is deemed the most reliable mechanism to secure exchange, it is remarkable that trust-based relations-built upon family relations, homogeneous ethnic networks, and repeat interactions-were able to sustain the diamond trade for as long as they did. Much more curious than the rise of vertical integration in the diamond chain might be how the industry was able to avoid such integration for so long. To be sure, trust, social networks, and family business can sustain trade while avoiding the bureaucratic inefficiencies of 
vertical integration. But the organizational efficiencies of vertical integration are apparently overwhelming with the growth of modernization of the marketplace. ${ }^{10}$

Fourth, and perhaps most interesting, what could be described as the rise and fall of trust illustrates both the possibilities and the fragility of trust-based exchange. In other words, both the diamond industry's capacity to sustain cooperation and the eventual demise of that cooperation offer lessons about the sustainability of trust-based exchange in the modern world. Reputation mechanisms and their underlying coordinated punishments are sensitive to their institutional environment, and changes in technology, geopolitics, and culture can disrupt a cooperative equilibrium. A lifecycle to trust-based exchange suggests that success often causes eventual demise as stateless networks to grow beyond their sustainable size.

It is indeed unfortunate to see dishonesty imbue an industry that had become the paradigm for trust. Alternatively, it is remarkable that institutional and historical circumstances enabled such trust to thrive for so long. In a world where cooperation is much more the exception than the rule, where coercive legal institutions are necessary to sustain cooperation and govern commerce, this one (albeit temporary) instance of trust-based exchange and self-sustaining cooperation illustrates the richness of private institutions and the possibilities of private governance. ${ }^{11}$

\section{REFERENCES}

Ashreena, Tanya \& A. Ananthalakshmi. 2015. Fearing Defaults, Banks Rein in Credit to Jewellery Firms. Reuters. http://in.reuters.com/article/india-jewellers-credit-idINKBN0KP0M020150116.

Bain \& Co., Inc. 2014. The Global Diamond Report 2014. http://www.bain.com/ publications/articles/global-diamond-report-2014.aspx.

2015. The Global Diamond Report 2015. http://www.bain.com/Images/ FINAL\%20bain_diamond_report_2015_01122015.pdf.

Barzel, Yoram. 1977. Some Fallacies in the Interpretation of Information Costs. 20 J. Law Econ. 291-307.

10 For an explanation of the tradeoffs of alternative governance mechanisms, both specifically for diamond transactions and more generally, see Richman (2004); see generally Williamson (1975).

11 For a less generous interpretation of the rise and fall of trust in the diamond industry, see Even-Zohar (2017, p. 8) (One ought to ponder how it was possible that in a relatively short time-span, in less than one generation, the trust-based system largely collapsed. It is no more-and it won't come back.") 
Bernstein, Lisa. 1992. Opting Out of the Legal System: Extralegal Contractual Relations in the Diamond Industry. 21 J. Legal Stud. 115-157.

Diamond Dealers Club New York. DDC Membership Application, Declaration. http://www.nyddc.com/membership.html.

Diamond Helpers. 2015. Diamond Tutorial: Avoid the Scams 1-20. http://diamondhelpers.com/diamond-tutorials/diamond-scams-1-20/.

Even-Zohar, Chaim. 2007. From Mine to Mistress. rev. Edition.

2008a. Bourse Leadership, Arbitrations, and Fraudulent GIA Certificates, Diamond Intelligence Briefing, 26 February.

Even-Zohar, Chaim 2008b. Arbitration Justice in Absentia, Diamond Intelligence Briefing, 14 April.

Even-Zohar, Chaim. 2011. DDC New York: A Bourse in the Service of its President, Diamond Intelligence Briefing. https://www.diamondintelligence. $\mathrm{com} /$ magazine/magazine.aspx? id $=9862$.

Even-Zohar, Chaim 2015. A Splintering of the Pipeline: The Economic Threat of Synthetics on the Diamond Producers, Diamond Intelligence Briefing. http://www.thediamondloupe.com/depth/2015-07-20/splintering-pipelineeconomic-threat-synthetics-diamond-producers.

Even-Zohar, Chaim. 2017. The Collapse of Trust-Based Commerce, Diamond Intelligence Briefing, 13 August. http://www.diamondintelligence.com/maga zine/magazine.aspx?id $=14430$.

Golan, Edahn. 2013. Financing in the Diamond Industry, Idex Magazine. http:// edahn.com/images/Financing_in_the_Diamond_Industry-IDEX_Magaz ine_Oct_2013.pdf.

Granovetter, Mark. 1985. Economic Action and Social Structure: The Problem of Embeddedness. $91 \mathrm{Am}$. J. Sociol. 481-510.

Grief, Avner. 2006. Institutions and the Path to the Modern Economy: Lessons from Medieval Trade. New York: Cambridge University Press.

Hofmeester, Karin. 2013. Shifting Trajectories of Diamond Processing: From India to Europe and Back, from the Fifteenth Century to the Twentieth. $8 \mathrm{~J}$. Glob. Hist. 25-49.

India Brand Equity Foundation. Ministry of Commerce and Industry, Government of India. http://www.ibef.org/industry/gems-jewellery-india. aspx.

Kanfer, Stefan. 1993. The Last Empire: De Beers, Diamonds, and the World. Toronto: Harper Collins.

Kenney, Roy W. \& Benjamin Klein, 1983. The Economics of Block Booking. 26 J. Law Econ. 497-540.

Khanna, Summit. 2008. After Years, Kathiawaris Outshine Palanpuris in India Diamond Biz, DNA India. http://www.dnaindia.com/india/report-afteryears-kathiawaris-outshine-palanpuris-in-india-diamond-biz-1156574. 
Klein, Benjamin \& Keith. Leffler, 1981. The Role of Market Forces in Assuring Contractual Performance. 89 J. Pol. Econ. 615-641.

Kothari, Sanjay. 2015. Crunch Time for the Global Diamond Industry, GemKonnect. https://gemkonnect.wordpress.com/2015/07/02/crunchtime-for-the-global-diamond-industry/.

Kuryan, Vinod. 2015. De Beers Discount Deals Erode Diamond Prices, May Trigger Price War, GemKonnect. https://gemkonnect.wordpress.com/2015/ 10/27/de-beers-discount-deals-erode-diamond-prices-may-trigger-pricewar/.

Macher, Jeffrey \& Barak Richman. 2008. Transaction Cost Economics: An Assessment of Empirical Research in the Social Sciences. 10 Business Pol. $1-63$.

Milgrom Paul R., Douglas North, \& Barry Weingast. 1990. The Role of Institutions in the Revival of Trade: The Law Merchant, Private Judges, and the Champagne Fairs. 2 Econ. Pol. 1-23.

Munshi, Kaivan. 2011. Strength in Numbers: Networks as a Solution to Occupational Traps. 78 Rev. Econ. Stud. 1069-1101.

Murphy, Victoria. 2004. Romance Killer. Forbes.com. http://www.forbes.com/ global/2004/1129/016.html.

Oltuski, Alicia. 2011. Precious Objects: A Story of Diamonds, Family, and a Way of Life. New York: Scribner.

Rapaport, Martin. 2005. GIA's Bribery Scandal, The Rapaport Group. http:// www.diamonds.net/News/NewsItem.aspx?ArticleID $=13569$.

Rapaport, Martin 2013. Synthetics: The Sale of Synthetic Diamonds as Natural Is Challenging the Integrity of Our Diamond Industry-What Should We Do About It? The Rapaport Group. http://www.diamonds.net/Docs/ Synthetics/Sinthetics.pdf.

Rasmusen, Eric. 1989. A Simple Model of Product Quality with Elastic Demand. 29 Economic Letters. 281-283.

Reserve Bank of India. 2013. Master Circular-Rupee/Foreign Currency Export Credit and Customer Service To Exporters. https://rbi.org.in/scripts/BS_ ViewMasCirculardetails.aspx? $\mathrm{Id}=8132 \&$ Mode $=0$.

Richman, Barak D. 2004. Firms, Courts, and Reputation Mechanisms: Towards a Positive Theory of Private Ordering. 104 Colum. L. Rev. 2328-2368. 2006. How Communities Create Economic Advantage: Jewish Diamond Merchants in New York. 31 Law Soc. Inquiry 383-420.

2009a. Ethnic Networks, Extralegal Certainty, and Globalisation: Peering Into the Diamond Industry. In V. Gessner, ed., Contractual Certainty in International Trade: Empirical Studies and Theoretical Debates on Institutional Support for Global Economic Exchanges. Portland, OR: Hart. 
2009b. The Antitrust of Reputation Mechanisms: Institutional Economics and Concerted Refusals to Deal. 95 Va. L. Rev. 325-387.

2013. Interview with Diamantkwartier, Antwerp, Belgium. On file with author.

2015. Interview with Industry Observer. On file with author.

Roberts, Janine. 2003. Glitter \& Greed: The Secret World of the Diamond Cartel.

New York: Disinformation Books.

Shah, Jumana. 2008. Palanpuris Have Rivals for Global Diamond Throne, DNA

India. http://www.dnaindia.com/india/report-palanpuris-have-rivals-forglobal-diamond-throne-1200102.

Shelanski, Howard \& Peter Klein. 1995. Empirical Research in Transaction Cost

Economics: A Review and Assessment. 11 J. Law Econ. Org. 335-361.

Sherman, Abe. 2014. Synthetic Diamonds: Opportunity or Problem?, Buyers

Intelligence Group. http:/www.diamonds.net/Docs/Synthetics/Sinthetics. pdf.

Shield, Renée Rose. 2002. Diamond Stories: Enduring Change on 47th Street. Ithaca, NY: Cornell University Press.

Shnidman, Ronen. 2013. Online Jewelry's Growth Restraint: U.S. Jewelers

Adapt to Online Challenges. The Rapaport Group. http://www.diamonds. net/News/NewsItem.aspx?ArticleID =51502.

Shor, Russell. 1993. A Profile of Diamond People and Their History. Philadelphia,

PA: International Diamond Publications.

simplesightholder@gmail.com. On file with author.

Spar, Debora L. 2000. Forever: De Beers and U.S. Antitrust Law, Case 9-700-082,

Harvard Business School.

2006. Markets: Continuity and Change in the International Diamond

Market, 20 J. Econ. Econ. Perspect. 195-208.

Starr, Roger. 1984. The Editorial Notebook; The Real Treasure of 47th Street,

N.Y. Times, 26 March. http:/www.nytimes.com/1984/03/26/opinion/the-

editorial-notebook-the-real-treasure-of-47th-street.html.

Times of India. 2015. GJEPC to Conduct Probe into Diamond Grading Fraud. http:/timesofindia.indiatimes.com/city/surat/GJEPC-to-conduct-probeinto-diamond-grading-fraud/articleshow/49603779.cms.

Whitehouse, Kaja. 2017. Diamond Store Owner Accused of Stealing Gems from Other Dealers, N.Y. Post, 5 April. http://nypost.com/2017/04/05/diamondstore-owner-accused-of-stealing-gems-from-other-dealers/.

Williamson, Oliver. 1975. Markets and Hierarchies. New York: Free Press. 1993. Calculativeness, Trust, and Economic Organization, 36 J. Law \& Econ. 453-486. 
Zimnisky, Paul. 2014. De Beers Market Share to Rebound to 40\% with Canada's Gahcho Kué Diamonds. http://www.paulzimnisky.com/de-beers-marketshare-to-rebound-to-40-with-canada-s-gahcho-kue-diamonds.

\section{CASES CITED}

Abraham v. Diamond Dealers Club, Inc., 896 N.Y.S. 848 (N.Y. Sup. Ct. 2010), Affidavit of David Abraham (February 2009).

Sanghvi v. Diamond Dealers Club, Inc., No. 7601085 (N.Y. Sup. Ct. 2007), Affidavit of Nitin Sanghvi (March 28, 2007).

Stettner v. Twersky, No. 6602298/06 (N.Y. Sup. Ct. September 11, 2006). 